University of Chicago Law School

Chicago Unbound

Public Law and Legal Theory Working Papers

Working Papers

2014

\title{
Terrible Tools for Prosecutors: Notes on Senator Leahy's Proposal to 'Fix' Skilling v. United States
}

Albert W. Alschuler

Follow this and additional works at: https://chicagounbound.uchicago.edu/public_law_and_legal_theory

Part of the Law Commons

Chicago Unbound includes both works in progress and final versions of articles. Please be aware that a more recent version of this article may be available on Chicago Unbound, SSRN or elsewhere.

\section{Recommended Citation}

Albert Alschuler, "Terrible Tools for Prosecutors: Notes on Senator Leahy's Proposal to 'Fix' Skilling v. United States" (University of Chicago Public Law \& Legal Theory Working Paper No. 463, 2014).

This Working Paper is brought to you for free and open access by the Working Papers at Chicago Unbound. It has been accepted for inclusion in Public Law and Legal Theory Working Papers by an authorized administrator of Chicago Unbound. For more information, please contact unbound@law.uchicago.edu. 


\section{CHICAGO}

PUblic LAW AND Legal TheORY WORKING PAPER No. 463

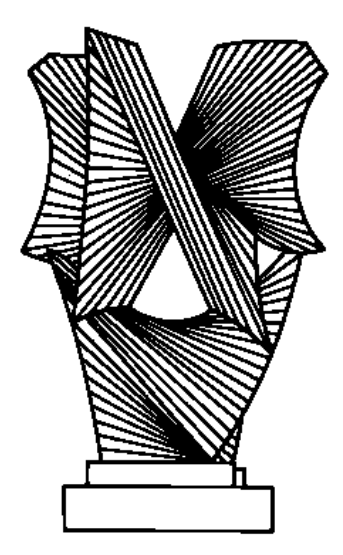

TERRIBLE TOOLS FOR PROSECUTORS: NOTES ON SENATOR LEAHY'S PROPOSAL TO “FIX" SKILLING V. UNITED STATES

Albert W. Alschuler

\section{THE LAW SCHOOL THE UNIVERSITY OF CHICAGO}

February 2014

This paper can be downloaded without charge at the Public Law and Legal Theory Working Paper Series: http://www.law.uchicago.edu/academics/publiclaw/index.html and The Social Science Research Network Electronic Paper Collection. 


\title{
TERrible ToOls For Prosecutors: Notes on SenAtor LEAHY’s Proposal to "FIX” SKILLING V. UNITED STATES
}

\section{Albert W. Alschuler*}

\begin{abstract}
This article examines a proposed legislative response to Skilling v. United States, a response approved by the Senate but never voted on by the House. It argues that federal mail fraud prosecutions disgrace American criminal justice and that amending the mail fraud statute to proscribe "undisclosed self-dealing” would make them worse.
\end{abstract}

\section{TABLE OF CONTENTS}

INTRODUCTION 1

I. BACKGROUND: FROM MAIL FRAUD TO MCNALLY TO THE HONEST SERVICES

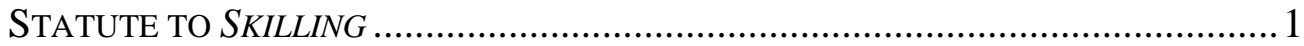

II. THE History OF SENATOR LEAHY’s PROPOSAL So FAR.................................. 4

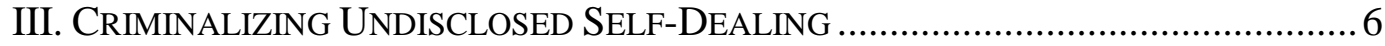

IV. THE FIRST ELEMENT: SELF-DEALING.....................................

A. The Ubiquity of Self-Dealing ............................................................. 8

B. The Uncertain Status of Campaign Contributions …................................ 9

C. Benefits Given to Friends and Relatives ................................................... 13

D. Benefits Given by Lobbyists and Other Friends.................................... 13

E. Advancing Financial Interests .......................................................... 14

F. Proving Purpose............................................................................. 9

V. The SECOND ElEMENT: Non-Disclosure in Violation OF

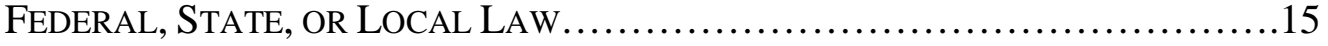

A. Standing Federalism on Its Head .......................................................... 15

B. Leahy's Paradox ................................................................................. 9

C. Federal, State, and Local Disclosure Rules: A Tangle.............................. 19

VI. The Procedural Consequences of Creating Another Form of

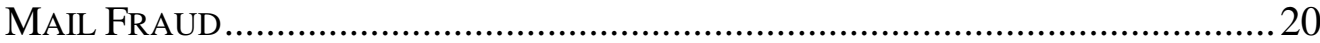

CONCLUSION: WHAT'S WRONG WITH CONGRESS? ............................................ 25

\footnotetext{
Chicago.

* Julius Kreeger Professor of Criminal Law and Criminology, Emeritus, The University of
} 


\section{TERrible TOOLS FOR PROSECUTORS: Notes ON SENATOR LEAHY’S PROPOSAL TO "FIX” SKILLING V. UNITED STATES}

\section{INTRODUCTION}

In 2010, Senator Patrick Leahy, the Chairman of the Senate Judiciary Committee, denounced Supreme Court's recent decision in Skilling $v$. United States ${ }^{1}$ and proposed restoring 20-year penalties for what he called "undisclosed self-dealing." In 2012, the Senate approved Senator Leahy's proposal without significant opposition, and the House Judiciary Committee endorsed the proposal unanimously. Because the majority leader of the House failed to bring it to a vote, however, the 112th Congress ended without enacting Senator Leahy's proposal. Congress continues to consider its response to Skilling.

This article maintains that Senator Leahy's proposal would make federal mail fraud prosecutions even more dreadful than they already are. Congress's near approval of this measure without notable criticism or opposition reveals an institution in which ill considered posturing on criminal justice issues still goes unchallenged.

\section{BACKGROUND: FROM MAIL FRAUD TO MCNALLY TO THE “HONEST SERVICES” STATUTE TO SKILLING}

The federal mail fraud statute, enacted in 1872, was the first statute to "federalize" crimes against private individuals that formerly had been prosecuted only by state and local authorities. The statute was aimed, not at dishonest government officials, but at swindlers who used the mails to peddle things like phony western mining stock. ${ }^{2}$ The statute forbids "devis[ing] any scheme or artifice to defraud" and then placing something in the mail for the purpose of executing the scheme. ${ }^{3}$ As the Supreme Court recognized in 1999, the 1872 statute did no more than incorporate traditional concepts of fraud. ${ }^{4}$ Fraud, a common law tort, consists of causing someone to part with his property or to act in other disadvantageous ways by lying. ${ }^{5}$

${ }^{1} 130$ S. Ct. 2896 (2010).

2 The sponsor of the measure declared that it would "prevent the frauds which are mostly gotten up in the cities . . by thieves, forgers, and rapscallions generally, for the purpose of deceiving and fleecing the innocent people in the country.” See McNally v. United States, 483 U.S. 350, 356 (1987) (quoting CoNG. GLOBE, 41st Cong., 3d Sess., 35 (1870) (remarks of Rep. Farnsworth)).

${ }^{3} 18$ U.S.C. § 1341.

${ }^{4}$ See Neder v. United States, 527 U.S. 1, 22-24 (1999).

${ }^{5}$ A treatise published shortly after Congress enacted the mail fraud statute described 
Federal prosecutors pressed courts to stretch the statute, and particularly in the 1970s, they did. By 1987, nearly every federal court of appeals had held that the statute outlawed deprivations of "the intangible right of honest services," and none had rejected this conclusion. ${ }^{6}$ These courts agreed that accepting a bribe or kickback deprived the public of its intangible right to honest services, and they said that other things did too. As the Supreme Court observed in Skilling, however, they were in "considerable disarray" about what the other things were. ${ }^{7}$

In 1987, the Supreme Court called a halt, one that turned out to be fleeting. In McNally v. United States, ${ }^{8}$ the Court held that the mail fraud statute outlawed deprivations of property, not of an ill-defined intangible right to honest services.

At the time of McNally, federal law had prohibited the bribery of federal officials for more than a century, ${ }^{9}$ and Congress had made it a federal crime to bribe state and local officials three years earlier. ${ }^{10}$ Dissatisfied with these straightforward prohibitions of bribery and the numerous other devices it had for prosecuting dishonest officials, ${ }^{11}$ the Justice Department complained that McNally had deprived it of an important tool in its fight against government corruption. It sought restoration of the honest-services gimmick, and Congress speedily complied. It enacted a new section of the mail fraud statute that read in full, "For the purposes of this chapter, the term 'scheme or artifice to defraud' includes a scheme or artifice to deprive

the elements of this tort:

It is a general rule of law that, in order to obtain redress or relief from the injurious consequences of deceit, it is necessary for the complaining party to prove that his adversary has made a false representation of material facts; that he made it with knowledge of its falsity; that the complaining party was ignorant of its falsity, and believed it to be true; that it was made with intent that it should be acted upon; and that it was acted upon by the complaining party to his damage.

Melville M. Bigelow, The LAW OF Fraud 1 (1877).

${ }^{6}$ See McNally v. United States, 483 U.S. 350, 362-64 \& nn.1-3 (1987) (Stevens, J., dissenting); United States v. Ochs, 842 F.2d 515, 521 (1st Cir. 1988).

${ }^{7}$ Skilling, 130 S. Ct. at 2929.

${ }^{8} 483$ U.S. 350 (1987).

${ }^{9}$ See Dixson v. United States, 465 U.S. 462, 491 (1984); 18 U.S.C. § 201.

10 See 18 U.S.C. $\S 666$ (prohibiting the bribery of any official of a state or local government that receives $\$ 10,000$ or more per year in federal benefits, as almost every state and local government does).

${ }^{11}$ See 18 U.S.C. $\S 1951$ (the Hobbs Act); 18 U.S.C. § 1952 (the Travel Act); 18 U.S.C. $\S \S$ 1961-62 (RICO); 18 U.S.C. § 1956 (the Money Laundering Control Act); 26 U.S.C. § 7201 (tax evasion). 
another of the intangible right of honest services." 12

Although the statute did not define the critical term, no Member of Congress appears to have said, “This thing is gibberish, and I won't vote for it." ${ }^{3}$ As William Stuntz observed, "[T]he story of American criminal law is a story of tacit cooperation between prosecutors and legislators, each of whom benefits from more and broader crimes." 14

The Supreme Court did not consider either the meaning or the constitutionality of the honest-services statute until Skilling $v$. United States in 2010. By that time, the government was able to cite substantial authority for the proposition that the statute proscribed "undisclosed self-dealing." 15

Although the government urged the Supreme Court to approve this standard, the Court not only rejected it but also took the unusual step of warning Congress that legislation approving it might be held unconstitutional. ${ }^{16}$ In an opinion by Justice Ginsburg, the Court declared that it could save the honest-services statute from a "vagueness shoal"17 only by confining it to the "solid core" that all the lower courts had recognized. ${ }^{18}$ The Court held, "[H]onest-services fraud does not encompass conduct more wide-ranging than the paradigmatic cases of bribes and kickbacks. . . . [N]o other misconduct falls within § 1346’s province.”19 Three justices-Justices Scalia, Thomas, and Kennedy—would have held the statute unconstitutionally vague. ${ }^{20}$

\section{THE History OF SENATOR LEAHY’s PROPOSAL So FAR}

Soon after Skilling, Senator Patrick Leahy, the Chairman of the Senate Judiciary Committee, declared that the Supreme Court had "sided with an Enron executive convicted of fraud" and "undermined Congressional efforts to protect hardworking Americans from powerful interests." ${ }^{21}$ Although the

1218 U.S.C. $\S 1346$.

${ }^{13}$ What became the honest services statute was joined with new mandatory minimum sentences in an omnibus drug control bill. The House approved this measure by a vote of 375 to 30 and the Senate by a vote of 87 to 3. Library of Congress, Bill Summary and Status, 100th Cong., H.R. 5210, available at http://thomas.loc.gov/cgibin/bdquery/z?d100:HR05210:@@@R.

${ }^{14}$ William J. Stuntz, The Pathological Politics of Criminal Law, 100 MiCH. L. REV. 505, 510 (2001).

15 See Skilling, 130 S. Ct. at 2932.

${ }^{16} I d$. at 2933 n.44.

${ }^{17}$ Id. at 2907.

${ }^{18}$ Id. at 2930.

${ }^{19}$ Id. at 2933.

${ }^{20}$ See id. at 2935 (Scalia, J., concurring in part and concurring in the judgment).

21 Statement of Senator Patrick Leahy, RESTORING KeY TOOLS TO COMBAT FraUd and Corruption After the Supreme Court's Skilling Decision, Hearing Before 
senator's denunciation of Skilling might be regarded as just the way politicians talk, consider for a moment how tawdry this talk is. In Skilling, the Supreme Court struggled to salvage and make sense of an apparently incomprehensible statute. As Senator Leahy described it, however, every member of a unanimous Court-Ruth Bader Ginsburg as well as Antonin Scalia-had sided with a dishonest Enron executive and powerful interests against hardworking Americans. ${ }^{22}$

To repair the damage wrought by Skilling, Senator Leahy introduced a measure he called "The Honest Services Restoration Act." 23 The Senate Judiciary Committee held a very brief hearing on this proposal. It styled this hearing "Restoring Key Tools to Combat Fraud and Corruption After the Supreme Court's Skilling Decision.”24

Members of Congress often speak of giving "tools" to prosecutors. ${ }^{25}$ They never speak of giving "tools" to defense attorneys and rarely speak of doing justice.

THE S. COMM. ON THE JUDICIARY at 1, 111th Cong. (2010).

22 The defendant in Skilling was indeed "an Enron executive convicted of fraud.”

23 S.3854, 111th Cong. (2010), available at https://www.govtrack.us/congress/bills/111/s3854/text. This initial version of Senator Leahy's proposal would have outlawed undisclosed self-dealing not only by public officials but also by the officers and directors of publicly traded corporations and private charities. The version later approved by the Senate would have proscribed self-dealing only by public officials. This article does not consider Senator Leahy's proposal for restricting self-dealing by private individuals.

${ }^{24}$ See RESTORING KEY TOOLS, supra note .

25 The full title of the USA Patriot Act is the Uniting and Strengthening America by Providing Appropriate Tools Required to Intercept and Obstruct Terrorism Act of 2001. See Pub. L. 107-56, 115 Stat. 272 (2001). The full title of the PROTECT Act is the Prosecutorial Remedies and Tools Against the Exploitation of Children Today Act of 2003. See Pub. L. No. 10-821, 117 Stat. 650 (2003).

Prosecutors seem unembarrassed to request new "tools" and offended when existing "tools” are threatened. After Attorney General Eric Holder endorsed the reduction of some mandatory minimum sentences, the National Association of Assistant United States Attorneys sent a public letter of protest:

[M]andatory minimum sentences are a critical tool in persuading defendants to cooperate, thereby enabling law enforcement officers to dismantle large drug organizations and violent gangs. Present law provides numerous opportunities for deserving defendants to avoid mandatory sentences through: cooperation in providing information about other criminals and criminal enterprises; plea bargaining, which resolves the vast majority of federal cases; [and other mechanisms].

Letter from the National Association of Assistant United States Attorneys to the Hon. Eric H. Holder, Jr., Jan. 27, 2014, available at http://www.mainjustice.com/wpadmin/documents-databases/187-1-NAAUSA-leter-to-Holder.pdf. 
In written statements submitted to the committee, two criminal defense attorneys maintained that prosecutors had abundant tools already. ${ }^{26}$ The only witnesses actually to appear before the committee were a representative of the Justice Department and three former federal prosecutors.

One of these witnesses, George J. Terwilliger III, endorsed a Skilling "fix" somewhat tentatively. He suggested that the issue required further study and that legislation prohibiting undisclosed self-dealing might better be located outside the mail fraud statute. ${ }^{27}$

The other witnesses were less hesitant. University of Florida Law Professor Michael L. Seigel complained, for example, that Skilling had left the federal government unable to convict of mail fraud (1) a state prosecutor who prosecuted an alleged murderer without disclosing the prosecutor's friendship with the murder victim, (2) a state legislator who sponsored legislation aiding his alma mater in language that did not make the identity of the benefitted university clear, and (3) "a disturbed employee of the Department of Homeland Security who exaggerates a threat for the sheer evil pleasure of causing a public panic." 28

According to a member of Senator Leahy's staff, the senator's proposal languished for a time because Republicans were concerned about prosecutorial misconduct that had occurred in the case of their late colleague, Senator Ted Stevens ${ }^{29}$-misconduct that led the Justice Department to dismiss the prosecution after Stevens had been convicted and lost his seat. ${ }^{30}$

By 2012, however, Leahy's proposal had substantial bipartisan support. Its sponsors in the House were James Sensenbrenner, the conservative Republican Chairman of the Criminal Justice Subcommittee of the Judiciary Committee, and Mike Quigley, a liberal Democrat. The House Judiciary Committee approved it by a vote of 30 to $0 .^{31}$

The Senate Judiciary Committee also approved the measure. Senator Leahy, a liberal democrat, and Senator John Cornyn, a conservative

${ }^{26}$ See RESTORING KeY TOOLS, supra note , at 48-61.

${ }^{27} \mathrm{Id}$. at $18-27$.

${ }^{28} \mathrm{Id}$. at 17.

${ }^{29}$ Conversation with Noah Bookbinder, Chief Counsel on Criminal Justice of the Senate Committee on the Judiciary, N.Y. City, Mar. 25, 2011.

${ }^{30}$ See Carrie Johnson \& Del Quentin Wilbur, Holder Asks Judge to Drop Case Against Ex-Senator: Justice Department Cites Prosecutors' Behavior During Stevens Trial, WASH. Post, Apr. 2, 2009, at A1; Del Quentin Wilbur, Judge in Stevens Dismissal Known for Tenacity, WASH. POsT, Apr. 10, 2009, at A3.

31 See Library of Congress, Bill Summary and Status, 112th Cong., H.R. 2572, available at http://thomas.loc.gov/cgi-bin/bdquery/z?d112:h.r.2572 (last visited Feb. 20, 2012). 
Republican, then offered it as an amendment to the STOCK Act, a bill whose main purpose was to prohibit insider trading by members of Congress. The Senate adopted the Leahy-Cornyn amendment by voice vote and then approved the bill 96 to $3 .^{32}$

Both the New York Times and the Washington Post endorsed the LeahyCornyn amendment. Neither paper offered any argument or analysis beyond the Times' claim that the amendment was "badly needed . . . to better prosecute corruption" 33 and the Post's declaration that it "would restore prosecutors' ability to go after official corruption." 34 All anyone needed to know was that the amendment was an anti-corruption measure and that corruption makes people very angry.

Bucking a strong political tide, the majority leader of the House, Republican Eric Cantor, did not include the Leahy-Cornyn proposal in the version of the STOCK Act he brought to a vote. ${ }^{35}$ After the House approved this version, the majority leader of the Senate, Democrat Harry Reid, blamed Republicans for blocking a conference committee to resolve differences between the two chambers' bills. Following a vote for closure, the Senate approved the House-approved measure by unanimous consent. ${ }^{36}$ The STOCK Act signed by the President did not include the Leahy proposal. $^{37}$

\section{CRIMINALIZING UnDISCLOSED SELF-DEALING}

As approved by the Senate, the Leahy proposal would create a new form of mail fraud-cundisclosed self-dealing." ${ }^{38}$ At the core of the proposed statute is a definition of this term. Unsurprisingly, the conduct proscribed by the statute would have two elements-self-dealing and non-disclosure.

First, an official must "act for the purpose, in whole or in material part," of furthering his own financial interest or that of any of a number of other people or organizations. They include his spouse, his minor child, his

${ }^{32}$ Congress Moves on Ethics, N.Y. TiMES, Feb. 4, 2012, at A20.

${ }^{33} \mathrm{Id}$.

34 The Senate Bids to Tighten Up on Insider Trading, WASH. PosT, Feb. 6, 2012, at A14. Both papers rejected an op-ed opposing the measure by former attorney general Edwin C. Meese III and me.

35 See Sung Min Kim, Eric Cantor Under Fire for STOCK Act Tweaks, POLITICO, Feb. 8, 20120, available at http://www.politico.com/news/stories/0212/72624.html.

${ }^{36}$ See Robert Pear, Insider Trading Ban for Lawmakers Clears Congress, N.Y. TIMES, Mar. 22, 2012, at A13.

${ }^{37}$ See Stop Trading on Congressional Knowledge Act of 2012, 126 Stat. 291 (2012).

38 The bill declares that "the term 'scheme or artifice to defraud' . . . includes a scheme or artifice by a public official to engage undisclosed self-dealing.” See Congressional Record, Feb. 2, 2012, 112th Cong., available at http://thomas.loc.gov/cgibin/query/F?r112:1:./temp/ r112h08WqO:e25901:. [improve this cite] 
business partner, and any person or organization from whom or which he "has received anything of value." 39 Although the proposal borrows the term self-dealing from the law of fiduciary obligation, it reaches conduct the law has not regarded as self-dealing before. Every agent must act in the interest of people he serves and not in his own self-interest, ${ }^{40}$ but self-dealing means self-dealing. Fiduciaries are not barred from contracting with people from whom they have received things of value, need not recuse themselves from decisions affecting the interests of these people, and need not disclose everything of value they have received.

Second, the official must knowingly falsify, conceal, cover-up, or fail to disclose "material information that is required to be disclosed by any Federal, State, or local statute, rule, regulation or charter applicable to the

39 The list also includes any business or organization of which the official is an employee, officer, director, trustee, or general partner; any individual, business or organization with whom or which he has any arrangement for employment or financial compensation; and any individual, business or organization with whom or which he is currently negotiating for employment or financial compensation.

The most sweeping item on the statutory list-anyone from whom the official "has received anything of value"-has an exception, and the exception has confused some readers. The proposed statute refers to receiving "anything of value, otherwise than as provided by law for the proper discharge of official duty, or by rule or regulation.”

The first part of this language_- "otherwise than as provided by law for the proper discharge of official duty”- - was apparently drawn from the federal gratuity statute, 18 U.S.C. § 201(c). The phrase refers to the payment of an official's salary or other authorized compensation for his official work. The added words “or by rule or regulation” probably refer to payment of the official's salary or other authorized compensation as well. The draftsman might have added these words to make clear that "provided by law" does not refer to statutory law alone; rules and regulations count too.

The placement of the additional words, however, is odd. The bill does not say "otherwise than as provided by statute, rule or regulation for the proper discharge of official duty"; it says "otherwise than as provided by law for the proper discharge of official duty, or by rule or regulation.” This placement has led some readers to conclude that the bill does not reach payments authorized by any rule or regulation even when the payments are not compensation for the performance of an official duty.

For example, a regulation prohibiting lobbyists from buying legislators' meals might allow lobbyists to host social events at which appetizers are served. See 5 CFR $\S$ 2635.203(b)(1). Some readers have thought that the bill would then exempt the receipt of appetizers because their receipt is "authorized by rule or regulation.”

This reading seems improbable. Exempting conduct from a prohibition does not "authorize" it for all purposes or exempt it from other prohibitions. Under the bill, a legislator's knowing violation of a law requiring the disclosure of a lobbyist's appetizers could be the predicate of a federal mail fraud prosecution if the legislator later acted to favor the appetizer provider's financial interests.

${ }^{40}$ See John H. Langbein, Questioning the Trust Law Duty of Loyalty: Sole Interest or Best Interest, 114 YALE L.J. 929, 958-63 (2005). Moreover, under the law of trusts, "transactions involving trust property entered into by a trustee for the trustee's own personal account [are] voidable without further proof.” Unif. Trust Code § 802 comment. 
public official.”

The word material in the phrase material information that is required to be disclosed does not mean what the word usually means in mail fraud prosecutions - having "a natural tendency to influence or [being] capable of influencing [a] decision." ${ }^{41}$ Instead, the bill defines "material information" as any information concerning the official's own financial interest (when he is alleged to have furthered his interest) or any information regarding his "association, connection, or dealings with" anyone from whom he has received something of value (when he is alleged to have furthered a benefactor's interest). ${ }^{42}$

\section{The FIRST ELEMENT: SELF-DEALING}

\section{A. The Ubiquity of Self-Dealing}

Self-dealing sounds sneaky, but public officials cannot avoid it. Every legislator engages in what the Leahy proposal calls self-dealing many times each year. A legislator who votes to reduce taxes, for example, "performs an official act for the purpose, in whole or material part, of furthering or benefitting a financial interest" of everyone on the statutory list-himself, his spouse, his employer, his business partner, and every person from whom he ever has accepted a beer, a fruitcake, an honorarium, or a fee for professional services.

Legislators commonly take official action to advance the financial interests of large groups of people. They approve bank bailouts, farm subsidies, tax breaks, rate increases, Medicare benefits, limits on credit card fees, and more. The benefitted groups are very likely to include people who have given things of value to the legislators. In addition, they are likely to include spouses, children, employers, business partners, and the legislators themselves. Under the Leahy proposal, any action taken to benefit a group that includes any of these people is self-dealing (although the self-dealing may be lawful either because the official has disclosed it or because no law requires its disclosure). ${ }^{43}$

${ }^{41}$ See Neder v. United States, 527 U.S. 1, 16 (1999).

42 See Congressional Record, Feb. 2, 2012, 112th Cong., available at http://thomas.loc.gov/cgi-bin/query/F?r112:3:./temp/ r1129FkULN:e256323:_] [Improve this cite.]

Although Senator Leahy's proposal would criminalize only conduct by public officials, donors and others could be prosecuted for conspiring with the officials and for complicity in their crimes.

${ }^{43}$ State regulations sometimes prohibit action to benefit an official's financial interest when "the effect on that interest . . . is greater than the effect on a substantial class of persons to which the [official] belongs as a member of a profession, occupation, industry or 


\section{B. The Uncertain Status of Campaign Contributions}

Skilling warned, "If Congress were to take up the enterprise of criminalizing 'undisclosed self-dealing by a public official . . . ,' it would have to employ standards of sufficient definiteness and specificity to overcome due process concerns." ${ }^{44}$ Senator Leahy therefore claimed on various occasions that his bill was "precise, careful legislation," ${ }^{45}$ that it was "carefully drafted to avoid ambiguity and lend certainty to the anticorruption law," 46 and that it had "unusual depth and precision in its definitions." ${ }^{47}$ Leahy made this claim even of the version of the bill he initially introduced-one so ineptly drafted that it would not have accomplished its purpose ${ }^{48}$ —and of the patched but ungrammatical version approved by the Senate. ${ }^{49}$

region.” See, e.g., Alaska Stat. § 24.60.030(g) (2012); R.I. Gen. Laws § 36-14-7(b) (2012). The Leahy proposal, however, has no comparable language. Benefitting a benefactor even as a member of a profession or other large group appears to be self-dealing.

${ }^{44} 130$ S. Ct. at 2933 n. 44.

45 Press Release, Senate Judiciary Committee Hearing Looks at Scope of Skilling Decision, Sept. 28, 2010, available at http://www.leahy.senate.gov/press/press_releases/release/?id=d8b2c597-548f-49cc-aaa99a888 jij88333dfdtgyyb bnbgy7cb8792a8.

${ }^{46}$ Press Release, Leahy, Casey Urge Senate Leaders to Push for Conference Committee on STOCK Act, Feb. 12, 2012, available at http://www.leahy.senate.gov/press/press_releases/?id=31e50b7f-Idab-4f1a-9419dbbe35094439.

47 Press Release, Comments of Senator Patrick Leahy on Public Corruption Amendment and the STOCK Act, Feb. 9, 2012, available at http://www.leahy.senate.gov/press/press_releases/release/?id=FA2892E5-FA31-42A0A2DC-50BAD999942D.

${ }^{48}$ See S.3854, 111th Cong. (2010). This bill declared that a public official engages in undisclosed self-dealing when he performs an official act for the purpose, in whole or in part, of furthering a financial interest of a person from whom he has received a thing of value and knowingly fails to disclose "material information regarding that financial interest in a manner that is required by any Federal, State, or local statute, rule, regulation or charter applicable to the public official." What statutes, rules, and regulations may require officials to disclose, however, are, not the "financial interests" of their benefactors, but the "things of value" the officials have received from them. Apparently no member of Congress or Congressional staffer noticed this glitch until I mentioned it at a conference attended by the Chief Counsel on Criminal Justice of the Senate Judiciary Committee on March 25, 2011. I should learn to keep my mouth shut.

${ }^{49}$ Note the shift from verb to noun in this version's description of the second element of undisclosed-self dealing: "and (B) the public official knowingly falsifies, conceals, or covers up material information that is required to be disclosed by any Federal, State, or local statute, rule, regulation, or charter applicable to the public official, or the knowing failure of the public official to disclose material information in a manner that is required by any Federal, State, or local statute, rule, regulation, or charter applicable to the public 
Although the Leahy proposal seems sufficiently precise to satisfy due process requirements, ${ }^{50}$ the senator's claim of "unusual depth and precision in its definitions" is open to doubt. One question the proposal leaves unanswered is whether an official performs an act partly to further his own financial interest when he performs this act partly to encourage contributions to his re-election campaign. Another is whether he performs an act partly to further the financial interest of someone from whom he has received a thing of value when he performs an act partly to benefit a campaign contributor.

The straightforward answer to these questions seems to be yes. Campaign contributions are cash, which, as Yogi Berra has observed, is just as good as money. ${ }^{51}$ In addition, spending campaign cash can enable a candidate to obtain a salaried position, something that unmistakably furthers his financial interest. And office holders may use campaign funds for purposes other than campaigning.

State law on the use of campaign funds often tracks federal law, and since 1989, federal law has prohibited federal office holders, former office holders, and current candidates from using campaign funds to pay personal expenses. ${ }^{52}$ Candidates and former candidates may, however, donate these funds to charities without limit, to political parties without limit, and to political campaigns other than their own within limits. They also may use campaign funds to pay legal expenses if charged with official misconduct, to buy furniture and art for their offices, and to pay other expenses of

official.” See Congressional Record, Feb. 2, 2012, 112th Cong., available at http:/thomas.loc.gov/cgi-bin/query/F?r112:3:./temp/ r1129FkULN:e256323: （emphasis added).

${ }^{50}$ Under the Leahy proposal, an official cannot engage in undisclosed self-dealing without knowingly violating a federal, state, or local law or regulation requiring the disclosure of a conflicting interest. When the predicate disclosure laws are sufficiently precise, officials can play it safe by complying with them. In Fort Wayne Books v. Indiana, 489 U.S. 46, 58 (1989), the Supreme Court indicated that the due process clause requires no more. It held that, because a person could not violate Indiana's RICO statute without also committing some predicate offense defined by another statute, the vagueness of the RICO statute itself did not matter. See id. at 58 ("Given that the RICO statute totally encompasses the obscenity law, if the latter is not unconstitutionally vague, the former cannot be vague either.”).

The Supreme Court's reasoning in Fort Wayne Books may not be entirely persuasive. Imagine a federal statute that forbids affecting interstate commerce by annoying others while violating any valid state law.

51 See Yogi Berra, WIKIQUOTE, http://en.wikiquote.org/wiki/Yogi_Berra (last visited Sept. 25, 2012) (noting Yogi Berra’s statement in an AFLAC commercial, "And they give you cash which is just as good as money”).

52 See U.S. Senate, Select Committee on Ethics, Senate Ethics Manual 154 n.428 (2003). 
campaigning and office holding. ${ }^{53}$ Officials have used these funds to enable their spouses to accompany them on work-related travel and to host extended gatherings at five-star resorts in Vail, Park City, Puerto Rico, Las Vegas, South Florida, and Bermuda. One member of Congress even has used campaign funds to pay herself $18 \%$ interest on loans from herself to her campaign. ${ }^{54}$ If people were asked outside the context of interpreting particular statutes whether officials further their financial interests and receive things of value when they obtain campaign contributions, most would find the question easy.

Nevertheless, taking official action to encourage campaign contributions and to benefit the interests of contributors is, one suspects, extremely common. Straining to save members of Congress from their folly, to save other elected officials too, and to prevent every knowing failure to report a campaign contribution from becoming a felony more serious than manslaughter, ${ }^{55}$ courts might hold that the Leahy proposal does not make taking official action to encourage campaign contributions "self-dealing."

\section{Benefits Given to Friends and Relatives}

Taking benefits in the form of campaign contributions might or might not shield an official from prosecution for undisclosed self-dealing. Channeling benefits to the official's spouse and others close to him, however, would preclude prosecution. Although taking official action to further the future financial interests of a spouse, minor child, or anyone else on the statutory list qualifies as self-dealing, acting to reward someone who previously has given something of value to a spouse does not. Unless the

${ }^{53}$ See id. at 154-55.

${ }^{54}$ See 60 Minutes: Washington's Open Secret: Profitable PACs (C.B.S. Television, Oct. 20, 2013), http://www.cbsnews.com/8301-18560_162-57608255/washingtons-opensecret-profitable-pacs/; Eric Lipton, A Loophole Allows Lawmakers to Reel in Trips and Donations, N.Y. TIMES, Jan. 20, 2014, at A1; Ken Silverstein, Beltway Bacchanal: Congress Lives High on the Contributor's Dime, Harper's Magazine, Mar. 2008, at 47; Dave Mann \& Abby Rapoport, Lifestyles of the Corrupt and Elected: How Do Texas Legislators Live Large on their $\$ 7200$ Salaries? Campaign Funds Pay for Lavish Perks and Personal Expenses, Courtesy of Special Interests, THE TeXAs OBSERVER, Jan. 16, 2011, available at http://www.texasobserver.ord/cover-story/lifestyles-of-the-corrupt-andelected; Thomas J. Cole, Lawmakers Use Campaign Funds for Expenses, AlBUQUERQUE JoURNAL, Feb. 15, 2012, at A1; Adam Schwartzman, Joe Bruno, Other Pols Use Campaign Funds to Pay Legal Expenses, VILLAGE Voice Blogs, Sep. 3, 2010, available at http://blogs.villagevoice.com/runninscared/2010/09/joe bruno other.php.

${ }^{55}$ The maximum penalty for voluntary manslaughter under federal law is 15 years. See 18 U.S.C. § 1112. The maximum penalty for mail fraud is ordinarily 20 years, but it becomes 30 years when the fraud affects either "a financial institution" or disaster-relief funds. See 18 U.S.C. § 1341. 
official himself has received a thing of value from a benefactor, taking official action to advance the benefactor's interests is permissible.

Similarly, an official engages in self-dealing when he benefits anyone who has ever employed him or patronized his private business. He does not engage in self-dealing when he benefits someone who has employed his spouse or patronized the spouse's business.

\section{Benefits Given by Lobbyists and Other Friends}

A banker might host a legislator's trip to an old golf course in Scotland, and the legislator then might vote in favor of bailing out the banking industry. Under the Leahy proposal, the legislator would have engaged in self-dealing.

The situation would change, however, if the banker paid large sums to a lobbyist to urge subsidies for the banking industry and if the lobbyist then hosted the trip to Scotland without any prompting from his client. ${ }^{56}$ In this situation, the legislator could defend against a charge of self-dealing by showing that he did not act for the purpose in whole or material part of favoring the lobbyist's financial interests; rather, he acted to benefit interests of the lobbyist's client. And although the client paid the lobbyist's fees, he did not provide the golf outing; he was in fact unaware of it. ${ }^{57}$

Gimmicky offenses invite gimmicky defenses. Permitting a lobbyist or other "bagman" to provide benefits could defeat a charge of undisclosed self-dealing.

Although legislators and other officials cannot avoid what the Leahy proposal calls self-dealing, a benefactor intent on corrupting an official probably could find ways around the proposal. Casting benefits in the form of campaign contributions might be enough, and if it were not, he could channel benefits to the legislator's spouse or could hire a lavish lobbyist.

\section{E. Advancing Financial Interests}

The Leahy proposal requires courts to distinguish between actions intended to advance benefactors' financial interests and actions intended to advance their other interests. Awarding a job, a scholarship, a grant, a lease, a contract, a rate increase, or a commercial license usually makes a benefactor richer, and approving a zoning change usually does too.

56 Cf. Wikipedia, List of Trips Funded by Jack Abramoff, http://en.wikipedia.org/wiki/List_of_trips_funded_by_Jack_Abramoff (last visited Nov. 13, 2013).

57 The client should avoid any conduct that might make him appear to be the source of the benefit provided-for example, reimbursing the lobbyist for the cost of the trip. 
Approving a pardon for a benefactor, however, probably does not further the benefactor's financial interest (although the benefactor's release from prison might enable him to take a job and although the pardon might make him eligible for an occupational license). Approving a low-digit license plate, making an honorific award, or inviting a benefactor to stay overnight in the Lincoln bedroom probably does not advance his financial interest either (although status symbols and obvious friendship with important officials could contribute to a benefactor's financial success). Approving a bridge sought by a benefactor probably would better his finances if the bridge improved access to his business, but it might not confer a financial benefit if the bridge merely made it easier for him to get home. The issue might be whether the bridge would reduce the benefactor's expenditures on gas.

\section{F. Proving Purpose}

The Leahy proposal makes an official's purpose crucial. He must "perform an official act for the purpose, in whole or material part, of furthering or benefitting a financial interest" of a person or group on the statutory list.

"Purpose" is more than knowledge; the word refers to an actor's goal, desire, or conscious object. ${ }^{58}$ If a legislator were to support a bank bailout after accepting a trip to Scotland from a banker, the legislator might testify that furthering his benefactor's financial interest was no part of his objective. Of course he understood that the bailout would advance the interest of his host, but the legislator's only purpose was to prevent a collapse of the economy and thereby serve the public.

Offering a defense like this one would make the merits and demerits of a challenged official action relevant. Did a lease, contract, grant, rate increase, or zoning change further the public interest, or was its purpose partly to feather a benefactor's private nest? Members of Congress who bemoan the federal deficit and maintain that the federal justice system is too poor to afford trials to more than a small minority of defendants apparently have no qualms about requiring courts to rehash at length the pros and cons of official actions and the purposes that lie behind them.

\section{THE SECOND ELEMENT: NON-DisClOSURE IN VIOLATION OF FEDERAL, STATE, OR LOCAL LAW}

\footnotetext{
${ }^{58}$ See Model Penal Code § 2.02(2)(a) (Proposed Official Draft 1962).
} 


\section{A. Standing Federalism on Its Head}

The Leahy proposal incorporates the disclosure requirements of state and local law, perhaps because Congress was unwilling to do the hard work of devising uniform national standards, perhaps because it doubted that such standards would be constitutional, ${ }^{59}$ or perhaps because it simply had no idea what disclosure requirements to impose.

Looking to state law, however, effectively moves trials for state regulatory violations into the federal courts and causes federal law to vary from state to state. In one state, the violation of a reporting requirement punishable only by private reprimand or public censure is transformed into a twenty-year federal felony. In a neighboring state, a failure to report the same information is no crime.

Three states—Idaho, Michigan, and Vermont-require neither legislators nor executive branch officials to disclose any gifts or honoraria they receive ${ }^{60}$ Officials in these states (including the state Senator Leahy represents, Vermont) might have little fear of prosecution for undisclosed self-dealing. Twelve additional states-Alabama, Connecticut, Iowa, Louisiana, Minnesota, Mississippi, Montana, New Mexico, North Dakota, South Dakota, Utah, and Wyoming - do not require legislators to disclose any gifts or honoraria they receive. ${ }^{61}$

Courts and commentators have argued that interpreting the term "honest services" to incorporate state standards promotes federalism. ${ }^{62}$ In fact, it turns federalism upside down. Every state's regulatory policy is a blend of prohibition, punishment, and forbearance. Federalizing a state's substantive regulations without its accompanying penalty structure and enforcement mechanisms diminishes state power. When a federal court assumes the role of a state agency and punishes state violations much more severely than the state legislature and state administrative authorities consider appropriate, it deprives the state of the ability to govern itself.

Just as Senator Leahy's proposal makes violations of noncriminal

${ }^{59}$ See text at note infra.

${ }^{60}$ Caitlin Ginley, 50 States and No Winners, State Integrity Investigation (a project of the Center for Public Integrity, Global Integrity, and Public Radio International), available at http://www.stateintegrity.org/state_integrity_investigation_overview_story.

${ }^{61}$ National Conference of State Legislatures, Personal Financial Disclosure: Gift and Honorarium Requirements (updated Dec. 2011), available at http://www.ncsl.org/legislatures-elections/ethicshome/personal-financial-disclosure-giftand-honoraria.aspx. Many of these states do forbid the receipt of specified gifts and honoraria.

${ }^{62}$ See, e.g., United States v. Brumley, 116 F.3d 728, 734-35 (5th Cir. 1997) (en banc); George D. Brown, Should Federalism Shield Corruption? Mail Fraud, State Law and PostLopez Analysis, 82 CORNELL L. REV. 225, 282-86 (1997). 
regulations and fineable misdemeanors predicates for federal mail fraud charges, the mail fraud charges become predicates for RICO and moneylaundering charges. ${ }^{63}$ Predicates piled on predicates are wondrous tools. ${ }^{64}$

\section{B. Leahy's Paradox}

Casting aside state enforcement mechanisms and penalty provisions offends basic principles of federalism, and incorporating some parts of a state regulatory scheme but not others does too.

States respond to what the Leahy proposal calls self-dealing in several ways. Sometimes they ignore it; sometimes they require its disclosure; and sometimes they prohibit it either by forbidding the creation of a conflicting interest (no official may accept a gift worth more than $\$ 50$ from a lobbyist) ${ }^{65}$ or by requiring recusal when a conflict of interest arises (a legislator may not vote on a bill if the legislator owns or has any financial interest in a business likely to be substantially affected by the bill). The Leahy proposal makes self-dealing a federal crime only when a state has taken the middle path, regulating self-dealing by requiring disclosure. The proposal does not reach either the kind of self-dealing a state ignores or the kind it forbids-presumably the least troublesome and the most troublesome kinds. ${ }^{66}$

Consider, for example, a state legislator who has not disclosed that his spouse owns a few shares of stock in an oil company and who votes to make a block of state land available for oil development. Under the Leahy proposal, this legislator's fate would turn on his state's laws.

In State A, no law or regulation might require disclosure of a spouse's stock holdings, and no law might require the legislator's recusal. In State A, the legislator would be guilty of no crime, state or federal.

In State B, a legislative rule might require a legislator to list in an annual report filed with his chamber's committee on ethics all stocks that he and his spouse own. Violation of this rule could lead to public or private reprimand or censure. In State B, the legislator would have committed a major federal felony.

In State C, a statute might declare that legislators may not vote on

${ }^{63}$ See 18 U.S.C. § 1961(1) (RICO); 18 U.S.C. § 1956(c)(7)(a) (money laundering).

${ }^{64}$ Senator Leahy's next book might be titled, Predicates Squared and Predicates Cubed: Turning Minor Misdemeanors into Fantastic Felonies in in Three Easy Steps.

${ }^{65}$ As noted above, several states do not require legislators to disclose the gifts and honoraria they receive but do forbid the receipt of some gifts and honoraria. See note supra.

${ }^{66}$ To be sure, a state may employ two or more regulatory strategies simultaneously. The fact that a campaign contribution is illegal, for example, does not excuse an official from reporting it. 
matters substantially affecting enterprises that they or their spouses own in whole or in part. Violating this statute might be a criminal misdemeanor, but in State $\mathrm{C}$ as in State A, the legislator would be guilty of no federal crime. Respect for federalism could not explain this result, for State C would punish the legislator's undisclosed self-dealing more severely than State B would. Under the Leahy proposal, engaging in self-dealing that a state prohibits is not a federal crime, but failing to report self-dealing that the state requires reported is a major felony.

It would be fairer and more effective for Congress to draft a national code of conduct for state officials, telling them what gifts and campaign contributions they may accept, what gifts and campaign contributions they must disclose, and what conflicts of interest require them to disqualify themselves from acting. Such a code almost certainly would be unconstitutional, however, ${ }^{67}$ and even if it were not, it would depart from almost everyone's sense of the appropriate division of state and federal authority. Although the fairer and more effective solution is unthinkable, incorporating some state laws but not others for no coherent reason and punishing violations of the incorporated laws much more severely than the states consider appropriate seems to command broad bipartisan support.

67 See National Fed’n of Indep. Bus. v. Sebelius, 132 S. Ct. 2566 (2012) (holding that Congress may not force states to approve substantial expansions of their Medicaid programs by threatening to withdraw federal funding from existing programs); Printz v. United States, 521 U.S. 898 (1997) (holding that Congress may not force state law enforcement officers to conduct background checks of handgun purchasers); New York v. United States, 505 U.S. 144 (1992) (holding that Congress may not force states either to accept ownership of radioactive waste or else to regulate it in accordance with federal instructions). In Garcia v. San Antonio Motor Transit Auth., 469 U.S. 528 (1985), the Supreme Court overruled a prior decision and held, five-to-four, that Congress could enact a minimum wage law applicable to the employees of state and local governments. The federal government's authority to assure minimum-wage parity among public and private workers, see id. at 554, does not suggest that it may direct the performance of state governments acting simply as state governments.

Congress enacted the mail fraud statute pursuant to the postal power rather than any of the powers at issue in Sebelius, Printz, New York v. United States, and Garcia. But the authority "to establish post offices," U.S. Const. art. I, § 8, cl. 7, surely does not include the power to promulgate a general code of conduct for state officials. Indeed, the thought that this power authorizes the federal prosecution of a state official for undisclosed self-dealing whenever any mailing by anyone is "incident to an essential part of the scheme," see Schmuck v. United States, 489 U.S. 705, 712 (1989), takes one aback. If any of the Framers imagined that the postal power would enable Congress to police the ethics of state officials, he had more sense than to say so out loud.

Some scholars have argued that Congress's power and duty to guarantee each state a republican form of government, U.S. Const. art. IV, $\S 4$, authorizes it to apply anticorruption legislation to state officials. See Adam H. Kurland, The Guarantee Clause as a Basis for Federal Prosecutions of State and Local Officials, 62 S. CALIF. L. REV. 367 (1989). 


\section{Federal, State, and Local Disclosure Rules: A Tangle}

Although public officials cannot avoid conduct that the Leahy proposal denominates self-dealing, the proposal punishes this conduct only when an official has knowingly failed to disclose "material information that is required to be disclosed by any Federal, State, or local statute, rule, regulation or charter." A critical issue is the appropriateness of treating violations of federal, state, or local disclosure requirements as federal mail fraud. These requirements are often vague, prolix, hyper-technical, and under-enforced. ${ }^{68}$

A New York commission concluded that the state's Ethics in Government Act "mandates absurdly excessive financial disclosure requirements" for more than 70,000 employees. ${ }^{69}$ An ABA Committee on Government Standards spoke of "a complex and formidable rule structure, whose rationale is increasingly obscure and whose operation is increasingly arcane."70 A director of the federal Office of Government Ethics complained, "[E]ven an employee who sincerely wants to follow the rules doesn't have the remotest chance of understanding them."

Abner Mikva, a former Member of Congress, former Chief Judge of the D.C. Circuit, and former White House counsel, declared, "[W]e already require the filing of too many forms. Every year all of our senior officials spend countless hours filling out countless disclosure forms. ... The reports are so complicated that most reviewers can't understand what they are reviewing, but they do serve as wonderful traps to snare the unwary

${ }^{68}$ The Illinois Governmental Ethics Act, for example, requires officials to disclose the economic interests of their spouses only when these interests are "constructively controlled" by the officials themselves. 5 ILCS 420/4A-102 (2012). In Stein v. Howlett, 289 N.E.2d 409, 579-80 (Ill. 1972), the Illinois Supreme Court held that this language was not unconstitutionally vague but offered no hint of what it meant.

Kathleen Clark has noted that "the Code of Federal Regulations contains over 130 pages of regulations governing required financial disclosure, conflicting financial interests, receipt of gifts, honoraria and payment for teaching, limitations on outside earned income, restrictions on employees' affiliation with law firms, rules governing current employees' ability to negotiate for future employment, and restricting former employees' employment options." Kathleen Clark, Do We Have Enough Ethics in Government Yet?: An Answer from Fiduciary Theory, 1996 U. ILL. L. REV. 57, 61 n.13 (1996).

${ }^{69}$ New York State Comm'n on Govt. Integrity, Restoring the Public Trust: A Blueprint for Government Integrity, 18 FORDHAM URBAN L.J. 173, 191 (1990-91).

70 ABA Comm. on Gov't Standards, Keeping Faith: Government Ethics \& Government Ethics Regulation, 45 ADM. L. REV. 287, 290 (1993).

${ }^{71}$ Jacob Weisberg, Springtime for Lobbyists, NeW REPUBLIC, Feb. 1, 1993, at 33, 38 (quoting Stephen J. Potts). 
official." $^{72}$

Funding for the enforcement of disclosure requirements is sometimes close to nonexistent. In Delaware, a two-person Public Integrity Commission is responsible for enforcing the ethical rules applicable to 48,000 public employees. ${ }^{73}$

Even better funded agencies are likely to investigate only when they receive complaints, which they almost never do. In its sixth year, the Tennessee Ethics Commission had yet to penalize anyone. ${ }^{74}$

The absence of effective enforcement can lead to frequent violation. The South Florida SunSentinel reported that, although Florida law required 34,959 state employees to report the receipt of every gift worth more than $\$ 100$, the number who reported any gift in 2008 was $385 .^{75}$

Perhaps Senator Leahy's proposed federalization of state reporting requirements would prompt greater compliance with these requirements by state officials. More probably, however, federal prosecutors would charge failing to report self-dealing so rarely that compliance rates would not be greatly affected. Prosecuting violations of state reporting requirements would be simply a way to bring down officials believed on other grounds to be malefactors. Congress would have added another handy tool to the prosecutors' overflowing kit. Sending prosecutor-picked malefactors to prison could become even easier (and perhaps more fun) than shooting gophers.

\section{The Procedural Consequences of Creating ANOTHER Form of MAIL FRAUD}

The Leahy proposal makes undisclosed self-dealing a form of mail fraud rather than a separate crime. Because some courts had treated undisclosed self-dealing as mail fraud prior to Skilling, the mail fraud statute seemed to be where a prohibition of self-dealing belonged. Prosecuting this conduct as a separate crime, however, would be far less objectionable. $^{76}$

The kindest assumption is that the senator and his staff had no idea how

72 Abner J. Mikva, From Politics to Paranoia: Misguided Ethics Laws Have Given Us More Mistrust, Not Less, WASH. POsT, Nov. 26, 1995, at C2.

${ }^{73}$ See Ginley, supra note .

${ }^{74}$ See id.

${ }^{75}$ See Brian Haas, Hidden Influence: Gifts to Politicians and Officials Go Unreported, and Few Are Punished for it, Disclosure Records Suggest, S. FlORIDA SunSEnTinel, Nov. 29, 2009, at $1 \mathrm{~A}$.

${ }^{76}$ The suggestion is that Congress should make whatever it wants to punish a crime rather than one form of another crime. If Congress wished, the jurisdictional "hook" could remain placing something in the mail. 
mail fraud prosecutions work. The following description draws heavily on the case of former Illinois Governor George H. Ryan, whom I represented in unsuccessful post-conviction proceedings, but many other cases resemble Ryan's. ${ }^{77}$ By throwing a mass of undifferentiated charges of unattractive conduct into a churning cauldron, prosecutors undermine core procedural protections and invite jurors to judge the defendant's character rather than his guilt or innocence of particular charges.

Were the Leahy proposal to become law, prosecutors would charge corruption cases as they do today by alleging a single fraudulent scheme. The indictment would declare that the scheme began at or before the moment the defendant took office and ended when he left office or was arrested. It would allege that the objects of this scheme were to defraud the public of money and property, to deprive the public of the intangible right of honest services, and to engage in undisclosed self-dealing. The alleged scheme would have lasted for years. In the case of Governor Ryan, the scheme allegedly began when he was elected as Illinois Secretary of State and ended when he left the governor's office twelve years later. ${ }^{78}$

The bulk of the indictment would consist of paragraphs beginning with the words "it was a part of the scheme" or "it was a further part of the scheme.” Each of these paragraphs would recite unattractive conduct. The defendant might be said to have used state property for political purposes, to have awarded low-digit license plates to campaign contributors, to have favored friends and benefactors in the award of government contracts, to have accepted a secret political consulting fee, to have violated a campaign

\footnotetext{
${ }^{77}$ Before I was associated with the Ryan case, I published a short commentary on the unfairness of this prosecution. See Albert W. Alschuler, The Mail Fraud \& Rico Racket: Thoughts on the Trial of George Ryan, 9 GREEN BAG 2D 113 (2006).

${ }^{78}$ The defendant might protest that the indictment was "duplicitous"-in other words, that it alleged many schemes, not just one-but he would probably lose. See, e.g., United States v. Caldwell, 302 F.3d 399, 408 (5th Cir. 2002); United States v. Morse, 785 F.2d 771, 774 (9th Cir. 1986); United States v. Warner, 2004 U.S. Dist. LEXIS 15727 at *67 (N.D. Ill.) (the case of Governor Ryan and his co-defendant Lawrence Warner). Courts embrace the fiction that everything done during the defendant's time in office was part of one grand plot. They treat a "scheme" as though it were a one-person conspiracy, borrowing precedents concerning the scope and duration of conspiracies without reflection. Ninety years ago, however, the courts took a more sensible view. See McClendon v. United States, 2 F.2d 660, 660-61 (6th Cir. 1924) ("[I]t has never yet been thought that the 'scheme to defraud' . . . could be found in the mere succession of diverse swindles, unrelated save as they had a common stage.”).

The pretense that all of the defendant's conduct was part of a single scheme would guide the trial judge in ruling on pretrial motions and conducting the trial. At the end of the trial, however, the judge would perform a breathtaking feat of prestidigitation and shrink the scheme to almost nothing. He would solemnly instruct the jury, "Ladies and gentlemen, you need not find the scheme charged in the indictment. Discovering any tiny scheme anywhere along the way will be enough.” See text at notes infra.
} 
pledge not to accept gifts worth more than $\$ 50$, to have instructed a subordinate to be more pleasant to a campaign contributor, to have shared confidential government information with private advisors, and more. All of the rotten things people said about him when threatened with prosecution themselves would appear in numbered paragraphs. Some of the alleged misconduct would have violated criminal or civil regulations, and some would not. The indictment of Governor Ryan included all of the allegations listed in this paragraph.

The allegations would not be listed under the headings "money-property fraud," "honest services fraud," and "undisclosed self-dealing." The indictment would simply declare that they were all "parts of the scheme" and that the scheme included the three unlawful objects.

After setting forth the alleged scheme for many pages, the indictment would charge several counts of mail fraud-each of them a mailing in furtherance of the unitary scheme. The mailings might be innocuous-for example, an election board's mailing of a certificate of the defendant's election to office. $^{79}$

The trial would continue for weeks or months as jurors heard descriptions of the defendant's allegedly improper behavior. The jurors would react initially to the drip, drip, drip of evidence without having been instructed on the law. ${ }^{80}$ The trial of Governor Ryan lasted nearly six months.

At the end of the trial, the judge would instruct the jury that the government need not prove all of the acts alleged to constitute the fraudulent scheme. Proving any act that established the elements of mail fraud would be enough. The issue presented to the jury would be whether any of the dirt thrown at the wall had stuck. ${ }^{81}$

The defendant might or might not be entitled to an instruction that all of the jurors must agree on which act or acts the government had shown. He might or might not be entitled to an instruction that the jurors must agree on

\footnotetext{
${ }^{79}$ In the case of Governor Ryan, the alleged mailings did relate to particular aspects of the alleged scheme and did permit the jury to separate some aspects of the scheme from others. My guess, however, is that the prosecutors would not have written the indictment that way if they had considered the issue more carefully. They rarely took less advantage than the law allowed.

80 Judge William Schwarzer compares the jurors' experience to watching a baseball game without being told the rules of baseball until the game ends. William W Schwarzer, Reforming Jury Trials: The Role of the Jury in Civil Dispute Resolution, 1990 U. CHI. LEGAL F. 119, 129-30.

${ }^{81}$ See, e.g., United States v. Reicin, 497 F.2d 563, 568 (7th Cir. 1994), United States v. Toney, 598 F.2d 1349, 1355-56 (5th Cir. 1979); Anderson v. United States, 369 F.2d 11, 15 (8th Cir. 1966).
} 
which of the three kinds of mail fraud had been proven. ${ }^{82}$ Even if the trial judge were to give one or both of these unanimity instructions, no one would know whether the jurors followed them, which act or acts they considered proven, which act or acts they considered legally sufficient, and which theory or theories of mail fraud they employed. The defendant would not be entitled to special verdicts on any of these issues. ${ }^{83}$

The jury would be unlikely to untangle the mass of evidence it had heard. Following the conviction of Governor Ryan, a newspaper reporter asked jurors which allegations had been most influential. Juror James Cwick replied, "There was a whole lot of stuff out there. You could pretty much take your pick." ${ }^{84}$ He added, "Each box, each piece of evidence was a brick, and if you put all the evidence together, it was a house." 85 Juror Kevin Rein explained, “It wasn’t a smoking gun. I went into deliberations with a feeling something was probably not on the up-and-up-and after 51/2 months [of trial] you have an idea." 86

Patrick Collins, the chief prosecuting attorney, commented, “This case

\footnotetext{
${ }^{82}$ On the same day the Supreme Court reversed the conviction in Skilling, it reversed another conviction for mail fraud in Black v. United States, 130 S. Ct. 2963 (2010). In Skilling, the trial court instructed the jurors that they must agree on which form of mail fraud the government established. In Black, no such instruction was given. See Jessica A. Roth, Alternative Elements, 59 UCLA L. REV. 170, 214 n.161 (2011).

Many court of appeals decisions touch on whether jurors must agree about which alleged acts in furtherance of the supposed scheme the defendant performed or schemed to perform and which form of mail fraud the government established. None of the decisions, however, appear actually to resolve either of these issues. See, e.g., United States v. Joshua, 648 F.3d 547, 553 (7th Cir. 2011); United States v. Lyons, 472 F.3d 1055, 1068-69 (9th Cir. 2007); United States v. Haber, 251 F.3d 881, 888-89 (10th Cir. 2001); United States v. Walker, 97 F.3d 253, 255 (2d Cir. 1996).

The Supreme Court has supplied a hornbook rule that leaves the critical questions unanswered. "A jury in a federal criminal case cannot convict unless it finds that the government has proved each element" of an offense, but "a federal jury need not always decide unanimously ... which of several possible means the defendant used to commit an element of a crime.” Richardson v. United States, 526 U.S. 813, 817 (1999).

${ }^{83}$ Whether to submit special interrogatories to the jury is left to the trial judge's discretion, and judges have submitted them in some mail fraud cases. See, e.g., United States v. Joshua, 548 F.3d 547, 553-54 (7th Cir. 2011). Nevertheless, "[s]pecial verdicts in the criminal law are disfavored.” See, e.g., United States v. Townsend, 924 F.2d 1385, 1413 (7th Cir. 1991); United States v. Roman, 870 F.2d 65, 73 (2d Cir. 1989); United States v. Collamore, 868 F.2d 24, 28 (1st Cir. 1989).

${ }^{84}$ James Janega \& Tom Rybarczyk, Small Details Painted Picture of Corruption, Chicago Tribune, Apr. 18, 2006, at C1.

${ }^{85}$ Susan Kuczka, Tom Rybarczyk \& Ted Gregory, Inside the Ryan Jury Room: Cooped Up for Weeks, Strangers Became a Team, ChICAGo TRIBUnE, Apr. 19, 2006, at C1. Cwick also observed, "The way I see things, I think I saw an up-close view of real life, how government works, how politics works.” Janega \& Rybarczyk, supra note .

${ }^{86} I d$.
} 
was tried witness by witness, piece of evidence by piece of evidence, and it was only by looking at the totality of the case that the true picture could be shown to this jury." ${ }^{87}$ It is no surprise that prosecutors describe the mail fraud statute as "our Stradivarius, our Colt 45, our Louisville Slugger, our Cuisinart." 88

American courts ordinarily exclude "other acts” evidence. Although a defendant accused of purse snatching may have been convicted a dozen times of purse snatching, the jury will not learn of his prior convictions. ${ }^{89}$ This evidence will be excluded because jurors should not be tempted to convict the defendant simply for being a bad person; they should judge the accusation of a particular wrongful act at a particular time.

Mail fraud trials, however, are extended smear campaigns. They have something in common the "hooliganism" trials of the Soviet Union and the People's Republic of China. ${ }^{90}$ These trials disgrace American justice, and Senator Leahy has found a way to make them worse.

\section{CONCLUSION: WHAT’S WRONG WITH CONGRESS?}

When a lawyer reviews a proposed will, trust, lease, statute, or other document, he typically asks whether the language of this document will do what it was intended to do, whether it will do things it was not intended to do, and whether it will be fairly and effectively implemented. No member of Congress and no staff member, however, seems to have adverted to the defects of the Leahy proposal described in this article. Although many people on Capitol Hill are law school graduates and members of the bar, there appear to be no lawyers there.

The story this article has told about Senator Leahy's proposal echoes

${ }^{87}$ Matt O’Connor \& Rudolph Bush, Ryan Guilty: A Juror's View, CHICAGo TribunE, Apr. 18, 2006, at C1.

${ }^{88}$ Jed S. Rakoff, The Federal Mail Fraud Statute (Part I), 18 DuQ. L. REV. 771, 771 (1980).

${ }^{89}$ See Fed. R. Ev. 404(b).

${ }^{90}$ China abolished the crime of hooliganism in 1997, but one defendant convicted of this crime remained in prison in 2011. See Quan Li, Lawyer Seeks Pardon for China's Last Hooligan, ChinaDaily.com, Jan. 7, 2011, http://www.chinadaily.com.cn/china/201101/07/content 11811269.htm. Russia still punishes hooliganism, see David M. Herszenhorn, Anti-Putin Stunt Earns Punk Band Two Years in Jail, N.Y. Times, Aug. 17, 2012, at A1, but the Russian statute proscribing hooliganism is more precise than the statute proscribing honest-services fraud in the United States. See Criminal Code of the Russian Federation, Art. 213 (defining hooliganism as "a gross violation of public order which expresses patent contempt for society, attended by violence against private persons or by the threat of its use, and likewise by the destruction or damage of other people's property"), available at http://www.russian-criminalcode.com/PartII/SectionIX/Chapter24.html. 
the story of federal criminal law generally. It is a story of statutory sprawlof criminal statutes that reach well beyond the situations their authors apparently meant to address. Much, though not all, ${ }^{91}$ of this sprawl is attributable to Congress's use of vague, overbroad, and difficult-to-limit language. The tale could be told not only of the Leahy proposal but also of the mail fraud statute, the honest services statute, the Mann Act, the Hobbs Act, the false statements statute, the Money Laundering Control Act, the Continuing Criminal Enterprise Statute, RICO, and many sentencing and forfeiture provisions.

When federal criminal statutes sprawl out of control, Congress almost never reins them back. Cutting back would invite charges of depriving prosecutors of important tools and of not caring about particular forms of criminal conduct. Members of Congress understand how easy it is for opponents to make these charges and how difficult it is to respond. Moreover, members have little incentive to engage in good legislative housekeeping when they can score points by voting to add another flashy tool to the prosecutor's kit. In the area of criminal justice, the only press good housekeeping is likely to get is bad press.

Nearly 50 years ago, Congress approved and President Johnson appointed a bipartisan commission to draft a new federal criminal code. At the time, roughly two-thirds of the states recently had revised or were in the process of revising or their own codes to incorporate proposals offered by the American Law Institute's Model Penal Code. ${ }^{92}$ The federal criminal code was less chaotic then than it is now, but then as now, it consisted of myriad ad hoc accretions to an archaic nineteenth-century core. After laboring for several years, the National Commission on Reform of Federal Criminal Law, headed by former Governor Edmund G. Brown of California, presented its draft in $1971 .{ }^{93}$

Nearly everyone praised this draft. Then partisans on both sides of the aisle sought to improve it. Despite the draft's uncontroversial core, it sank amidst disputes about the death penalty, the insanity defense, the protection of official secrets, and a few other issues. ${ }^{94}$

The wrangling and posturing that torpedoed revision of the federal criminal code in the early 1970 s occurred in a less partisan era than ours. ${ }^{95} \mathrm{~A}$

${ }^{91}$ See Stephen F. Smith, Proportionality and Federalization, 91 VA. L. REV. 879, 884 (2005) ("Far from being innocent bystanders in the federalization of crime, federal judges have been all too willing to construe federal crimes expansively.”).

92 See Model PenAl Code (Proposed Official Draft 1962).

93 See Final Report of the NATIONAL COMMission ON REFORM OF FEDERAL CRIMINAL LAW (1971).

${ }^{94}$ Louis Schwartz told the disheartening story in Louis B. Schwartz, Reform of the Federal Criminal Laws: Issues, Tactics, and Prospects, 41 L. \& ConTEMP. ProB. 1 (1977).

95 See. e.g., Mickey Edwards, The Parties Versus the PeOPle: How to Turn 
comparable effort would be hopeless today. ${ }^{96}$ In 2011, even Senator Webb’s proposal to establish a bipartisan commission to study the criminal justice system - a proposal supported by groups as diverse as the National Sheriffs' Association, the Fraternal Order of Police, the ACLU, and the NAACPfailed to attract enough votes to overcome a Senate filibuster. ${ }^{97}$

Congress's hyper-partisanship may be the primary reason for its low approval ratings, ${ }^{98}$ and its undemocratic procedures may contribute to public disapproval as well. Republicans and Democrats were united in supporting the Leahy proposal, however, and no member of Congress opposed this measure publically. In the last Congress, only woefully undemocratic procedure kept this measure from becoming law. The majority leader of the House thwarted the will of an overwhelming majority of both houses and did so without explanation.

Although a fiscal crisis may be bringing the era of mandatory minimum sentences and ever increasing prison populations to an end, ${ }^{99}$ the Leahy

REPUBLICANS AND DEMOCRATS INTO AMERICANS (2012); Lee Hamilton, Why is Congress So Partisan?, Center on Congress at Indiana University, http://72.32.58.69/radio_commentaries/why_is_congress_so_partisan.php; Lugar Unloads on "Unrelenting” Partisanship, POLITICO, May 9, 2012, http://www.politico.com/blogs/on-congress/2012/05/lugar-unloads-on-unrelentingpartisanship-122891.html; Olympia J. Snowe, How the Public Can Save the Senate, WASH. Post, Mar. 4, 2012, at A23; Alan I. Abramowitz \& Kyle L. Saunders, Is Polarization $a$ Myth?, 70 J. OF POLITICS 542 (2008).

96 The Subcommittee on Crime, Terrorism, and Homeland Security of the House Judiciary Committee did hold hearings on criminal code revision in 2011. See CRIMINAL Code Modernization AND Simplification ACt of 2011, HeARing Before SubCOMm. ON CRIME, TERrorism, AND HOMELAND SECURITY OF THE H. COMM. ON THE JUdiCIARY, 112th Cong. (2011). It considered a proposed 1200-page codification that would have moved drug and immigration offenses currently set forth in other titles to Title 18, eliminated some duplicative provisions, provided uniform definitions of some inconsistently defined terms, used the word "knowingly" to describe the mens rea required for most malum in se offenses, and created general attempt and conspiracy provisions to punish attempts and conspiracies as severely as completed crimes. The measure did not offer the sort of comprehensive revision and simplification the Brown Commission proposed, and it has not been enacted.

${ }^{97}$ Mike Sacks, Jim Webb's Criminal Justice Overhaul Commission Blocked Again in Senate, HufFINGTON POST, Oct. 20, 2011, http://www.huffingtonpost.com/2011/10/20/jimwebb-criminal-justice-commission-blocked-senate_n_1022722.html; David Rogers, Republicans Block Justice Review Proposal in Senate, Politico, Oct. 20, 2011, http://www.politico.com/news/stories/1011/66491.html.

98 See Sarah Dutton, Jennifer De Pinto, Anthony Salvanto \& Fred Bakus, Views of Obamacare Improve, but are Still Negative Overall, CBS NEWS, Dec. 19, 2013, http://www.cbsnews.com/news/views-of-obamacare-improve-but-are-still-negative-overall/ (reporting that $10 \%$ of Americans approve of Congress's performance while $83 \%$ disapprove).

99 The federal prison population increased in 2012 but at lower rate than in earlier years. Nine states reduced their prison populations substantially. See Erica Goode, U.S. 
proposal and its reception indicate that posturing on criminal justice issues is not over. ${ }^{100}$ A flaw as serious as political partisanship may be members' lack of motivation to do quiet work that promises little or no political payoff (or to ensure that staff members do this work or to find academic and other lawyers willing to do it for free).

I have been tempted on occasion to cast aside my accustomed role as a lawyer and to write a work of political theory with the title "Democracy Sucks." Every mention of my thesis, however, prompts some sage to recite Winston Churchill's line, "[D]emocracy is the worst form of Government except all others . . .." ${ }^{101}$ Critics of my thesis apparently think only of monarchy, dictatorship, and hereditary aristocracy when they consider alternatives to democracy, and these alternatives are indeed worse.

The Framers of the U.S. Constitution, however, fully embraced my thesis and pointed to a better alternative. On the first full day of the Constitutional Convention, Edmund Randolph declared, "None of the [state] constitutions have provided sufficient checks against democracy." 102 Elbridge Gerry later told the convention, "The evils we experience flow from the excess of democracy." 103 James Madison wrote in Federalist 10 that pure democracies were "spectacles of turbulence and confusion." 104 Alexander Hamilton proclaimed that the ancient democracies "never possessed one feature of good government." 105

The Framers never spoke of democracy without disparaging it, and the Constitution they drafted did not speak of it at all. Although this document provided for the direct election of members of the House of Representatives, it provided other means of selecting all other federal officials, including the President, members of the Senate, and justices of the Supreme Court. The Framers would have disapproved of a government like ours in which legislators "are essentially campaigning and raising money all the time." 106 They hoped to create a "mixed" system in which officials

Prison Populations Decline, Reflecting New Approach to Crime, N.Y. TIMES, July 26, 2013, at A11.

100 Moreover, government corruption is a well chosen crime du jour. It stirs the resentful sentiments of almost everyone, including members of both the Occupy Wall Street and Tea Party movements.

1017 Winston Churchill, W. S. Churchill, His COMPlete SPEeches, 1897-1963 at 566 (1974).

1021 ReCords of the Federal Convention of 1787 at 26-27 (Max Farrand, ed., 1911).

${ }^{103} \mathrm{Id}$. at 48.

104 The Federalist No. 10 at 51-52 (James Madison) (J. R. Pole, ed., 2005).

1055 THE PAPERS OF AlEXANDER HAMILTON 39 (Harold C. Syrett, et al., eds., 19611987).

106 See Anthony Corrado, Running Backward: The Congressional Money Chase, in The Permanent Campaign and Its Future 75 (Norman J. Ornstein \& Thomas E. Mann, 
would have enough distance from politics to consider the public good.

When asked at the end of the Constitutional Convention what form of government the convention had approved, Benjamin Franklin is supposed to have said, “A republic if you can keep it." ${ }^{107}$ Americans have not kept it. ${ }^{108}$ Politicians hire expert consultants to determine how to push our hot buttons. They then push these buttons without much regard for how their proposals are likely to work in practice.

eds., 2000).

107 Papers of Dr. James McHenry on the Federal Constitution of 1787, 11 AM. Hist. REV. 595, 618 (1906).

${ }^{108}$ In the 1980s, a brief republican revival among legal scholars seemed to evaporate when critics noted that earlier republicans owned slaves, limited the franchise to male property owners, and were disagreeably elitist in a number of other ways. See, e.g., Linda K. Kerber, Making Republicanism Useful, 97 YALE L.J. 1663, 1668-89 (1988). My contemplated work of political theory would not embrace all of the Framers' positions. 
Readers with comments may address them to:

Professor Albert W. Alschuler

University of Chicago Law School

1111 East 60th Street

Chicago, IL 60637 


\section{The University of Chicago Law School Public Law and Legal Theory Working Paper Series}

For a listing of papers 1-400 please go to http://www.law.uchicago.edu/publications/papers/publiclaw.

401. Gary Becker, François Ewald, and Bernard Harcourt, "Becker on Ewald on Foucault on Becker” American Neoliberalism and Michel Foucauilt’s 1979 Birth of Biopolitics Lectures, September 2012

402. M. Todd Henderson, Voice versus Exit in Health Care Policy, October 2012

403. Aziz Z. Huq, Enforcing (but Not Defending) “Unconstitutional” Laws, October 2012

404. Lee Anne Fennell, Resource Access Costs, October 2012

405. Brian Leiter, Legal Realisms, Old and New, October 2012

406. Tom Ginsburg, Daniel Lnasberg-Rodriguez, and Mila Versteeg, When to Overthrow Your Government: The Right to Resist in the World's Constitutions, November 2012

407. Brian Leiter and Alex Langlinais, The Methodology of Legal Philosophy, November 2012

408. Alison L. LaCroix, The Lawyer's Library in the Early American Republic, November 2012

409. Alison L. LaCroix, Eavesdropping on the Vox Populi, November 2012

410. Alison L. LaCroix, On Being “Bound Thereby,” November 2012

411. Alison L. LaCroix, What If Madison had Won? Imagining a Constitution World of Legislative Supremacy, November 2012

412. Jonathan S. Masur and Eric A. Posner, Unemployment and Regulatory Policy, December 2012

413. Alison LaCroix, Historical Gloss: A Primer, January 2013

414. Jennifer Nou, Agency Self-Insulation under Presidential Review, January 2013

415. Aziz Z. Huq, Removal as a Political Question, February 2013

416. Adam B. Cox and Thomas J. Miles, Policing Immigration, February 2013

417. Anup Malani and Jonathan S. Masur, Raising the Stakes in Patent Cases, February 2013

418. Ariel Porat and Lior Strahilevits, Personalizing Default Rules and Disclosure with Big

Data, February 2013

419. Douglas G. Baird and Anthony J. Casey, Bankruptcy Step Zero, February 2013

420. Alison L. LaCroix, The Interbellum Constitution and the Spending Power, March 2013

421. Lior Jacob Strahilevitz, Toward a Positive Theory of Privacy Law, March 2013

422. Eric A. Posner and Adrian Vermeule, Inside or Outside the System? March 2013

423. Nicholas G. Stephanopoulos, The Consequences of Consequentialist Criteria, March 2013

424. Aziz Z. Huq, The Social Production of National Security, March 2013

425. Aziz Z. Huq, Federalism, Liberty, and Risk in NIFB v. Sebelius, April 2013

426. Lee Anne Fennell, Property in Housing, April 2013

427. Lee Anne Fennell, Crowdsourcing Land Use, April 2013

428. William H. J. Hubbard, An Empiritcal Study of the Effect of Shady Grove v. Allstate on Forum Shopping in the New York Courts, May 2013

429. Daniel Abebe and Aziz Z. Huq, Foreign Affairs Federalism: A Revisionist Approach, May 2013

430. Albert W. Alschuler, Lafler and Frye: Two Small Band-Aids for a Festering Wound, June 2013

431. Tom Ginsburg, Jonathan S. Masur, and Richard H. McAdams, Libertarian Paternalism, Path Dependence, and Temporary Law, June 2013

432. Aziz Z. Huq, Tiers of Scrutiny in Enumerated Powers Jurisprudence, June 2013 
433. Bernard Harcourt, Beccaria's On Crimes and Punishments: A Mirror of the History of the Foundations of Modern Criminal Law, July 2013

434. Zachary Elkins, Tom Ginsburg, and Beth Simmons, Getting to Rights: Treaty

Ratification, Constitutional Convergence, and Human Rights Practice, July 2013

435. Christopher Buccafusco and Jonathan S. Masur, Innovation and Incarceration: An Economic Analysis of Criminal Intellectual Property Law, July 2013

436. Rosalind Dixon and Tom Ginsburg, The South African Constitutional Court and SocioEconomic Rights as 'Insurance Swaps', August 2013

437. Bernard E. Harcourt, The Collapse of the Harm Principle Redux: On Same-Sex Marriage, the Supreme Court's Opinion in United States v. Windsor, John Stuart Mill's essay On Liberty (1859), and H.L.A. Hart’s Modern Harm Principle, August 2013

438. Brian Leiter, Nietzsche against the Philosophical Canon, April 2013

439. Sital Kalantry, Women in Prison in Argentina: Causes, Conditions, and Consequences, May 2013

440. Becker and Foucault on Crime and Punishment, A Conversation with Gary Becker, François Ewald, and Bernard Harcourt: The Second Session, September 2013

441. Daniel Abebe, One Voice or Many? The Political Question Doctrine and Acoustic Dissonance in Foreign Affairs, September 2013

442. Brian Leiter, Why Legal Positivism (Again)? September 2013

443. Nicholas Stephanopoulos, Elections and Alignment, September 2013

444. Elizabeth Chorvat, Taxation and Liquidity: Evidence from Retirement Savings, September 2013

445. Elizabeth Chorvat, Looking Through' Corporate Expatriations for Buried Intangibles, September 2013

446. William H. J. Hubbard, A Theory of Pleading, Litigation, and Settlement, November 2013

447. Tom Ginsburg, Nick Foti, and Daniel Rockmore, "We the Peoples": The Global Origins of Constitutional Preambles, November 2013

448. Lee Anne Fennell and Eduardo M. Peñalver, Exactions Creep, December 2013

449. Lee Anne Fennell, Forcings, December 2013

450. Jose Antonio Cheibub, Zachary Elkins, and Tom Ginsburg, Beyond Presidentialism and Parliamentarism, December 2013

451. Nicholas Stephanopoulos, The South after Shelby County, October 2013

452. Lisa Bernstein, Trade Usage in the Courts: The Flawed Conceptual and Evidentiary Basis of Article 2's Incorporation Strategy, November 2013

453. Tom Ginsburg, Political Constraints on International Courts, December 2013

454. Roger Allan Ford, Patent Invalidity versus Noninfringement, December 2013

455. M. Todd Henderson and William H.J. Hubbard, Do Judges Follow the Law? An Empirical Test of Congressional Control over Judicial Behavior, January 2014

456. Aziz Z. Huq, Does the Logic of Collective Action Explain Federalism Doctrine? January 2014

457. Alison L. LaCroix, The Shadow Powers of Article I, January 2014

458. Eric A. Posner and Alan O. Sykes, Voting Rules in International Organizations, January 2014

459. John Rappaport, Second-Order Regulation of Law Enforcement, February 2014

460. Nuno Garoupa and Tom Ginsburg, Judicial Roles in Nonjudicial Functions, February 2014

461. Aziz Huq, Standing for the Structural Constitution, February 2014

462. Jennifer Nou, Sub-regulating Elections, February 2014

463. Albert W. Alschuler, Terrible Tools for Prosecutors: Notes on Senator Leahy's Proposal to "Fix" Skilling v. United States, February 2014 